\title{
Taxonomic Survey of Nickel Hyperaccumulating Plants in a Mining Site on Luzon Island, Philippines
}

\author{
Quinn Ericka B. Bayas, Shamaine Anne SJ. Salvador, Elena M. Ragragio*and Jasper John A. Obico
}

\begin{abstract}
Plants that accumulate large amounts of heavy metals can be useful for environmental phytoremediation. These hyperaccumulators are capable of tolerating high concentrations of metals which are otherwise toxic to non-hyperaccumulators. This study aimed to account and categorize hyperaccumulating plant species in the Lagonoy ophiolite complex located in Camarines Sur province on Luzon Island. Plants were collected from several sampling sites within the mining area, identified, and their nickel content was measured using AAS. A total of 44 species from 30 families were collected and classified into non-accumulators, hemiaccumulators, hyperaccumulators and hypernickelophores based on the nickel level ranges defined in the work of Fernando et al. (2013). Six species were classified as non-nickel accumulators, in which the nickel content was $<100$ ppm (1 ppm=1 $\mu \mathrm{g} \mathrm{Ni/g}$ dry matter). Twenty-one species were classified as hemiaccumulators, having 100-999 $\mu \mathrm{g} / \mathrm{g} \mathrm{Ni}$ levels. There were 11 species of hyperaccumulators with nickel content of $>1000 \mu \mathrm{g} / \mathrm{g} \mathrm{Ni}$ in dry matter and six hypernickelophores with nickel content of $>10000 \mu \mathrm{g} / \mathrm{g} \mathrm{Ni}$ in dry matter. The plant with the highest nickel content was Lygodium circinnatum (Burm.f.) Swartz. The potential of this fern as a phytoremediation plant is discussed.
\end{abstract}

KEYWORDS: heavy metals, mining, nickel hyperaccumulators, ophiolite complex, pollution

\section{INTRODUCTION}

Phytoaccumulation is one method that uses plants to extract metal contaminants from the soil and to transport and store these metals in the vegetative parts of the plant (Wang et al., 2010). Plants used in this process are called hyperaccumulators and they are capable of tolerating high concentrations of metals which are otherwise toxic to nonhyperaccumulators.

In the Philippines, studies of potential nickel hyperaccumulators in ultramafic soils have been conducted. One was done by Baker et al. (2000) in Mt. Bloomfield, Palawan in which they identified two woody species as nickel hyperaccumulators. The other two studies were by Fernando et al. (2013), wherein 9 native species from the Acoje mining site in the Zambales ophiolite complex were identified to hyperaccumulate nickel. A hypernickelophore, Phyllanthus

Department of Biology, College of Arts and Sciences, University of the Philippines-Manila, Padre Faura St., Ermita, Manila 1000

"Corresponding author: lenmragragio@gmail.com

Date Submitted: 13 January 2018

Date Accepted: 12 April 2018 securinegoides Merr. was identified in Surigao del Norte (Quimado et al., 2015). To contribute further to information regarding nickel hyperaccumulators in the Philippines, the researchers focused on identifying potential nickel hyperaccumulators from the Lagonoy ophiolite complex, an understudied ultramafic area in the Bicol region.

The Bicol region has significant deposits of gold, silver, lead, zinc, iron, nickel, chromite, copper and manganese, making mining one of its major sources of income (Department of Economic Research, 2005). Specifically, the Camarines Norte-Calaguas Island ophiolite complex, Lagonoy ophiolite complex in Camarines Sur, Rapu-Rapu in Albay and Aroroy, Masbate (Mines and Geosciences Bureau, 2010) are the chief sites of mining in the region, although the local government unit recently made efforts to prohibit mining in Lagonoy (Basmayor, 2014). According to the Department of Environment and Natural Resources (Mines and Geosciences Bureau, 2014), the Lagonoy Natural Biotic Area is one of the protected areas in Bicol Region which was declared by the law as a component of the National Integrated Protected Areas System (NIPAS).

Peridotites, as well as dunites and chromitites, are ultramafic rocks. This geochemistry makes the Lagonoy 
ophiolite a major source of commercial quantities of chromite and manganese, and to some extent, nickel (Department of Economic Research, 2005). Likewise, a study by Aloc (2003) characterized the natural vegetation in Mt. Isarog, situated west of Lagonoy, Camarines Sur and the current study site as part of the same mountain range. The findings showed that the vegetation was composed mostly of members of the Meliaceae, Euphorbiaceae, and Sapindaceae. At lower elevations, the most common species found are broad-leaved herbs, softwood trees and shrubs.

Nickel in the environment is naturally occurring at lower levels but long term contact can cause various health problems such as dermatitis. Respiratory, skin and cardiovascular effects have also been reported from the constant inhalation of nickel (Chashschin et al., 1994). The removal of these heavy metals from the environment with the use of phytoextractive vegetation can potentially contribute to a healthy environment. It is hoped that information regarding plants that accumulate nickel can contribute to the rehabilitation and restoration of ecosystems especially in ultramafic soils that are associated with mining areas. Likewise nickel in the mining areas can be removed by plants and mitigation of these areas by revegetation using hyperaccumulators of nickel can be an important step for mining companies to implement remediation steps.

\section{MATERIALS AND METHODS}

Collection Site. The Lagonoy ophiolite complex is located in the municipality of Lagonoy, province of Camarines Sur on Luzon Island and is situated at $13.44^{\circ} \mathrm{N}$ and $123.31^{\circ} \mathrm{E}$. Permission for sample collection within the mining site was secured from the Bicol Chromite and Manganese Corporation, the company currently operating on the site. A permit for sample collection outside of the mining site was obtained from the local government unit of the Municipality of Lagonoy. A police clearance was also obtained for security reasons.

Purposive sampling was done in four areas within the boundaries of the mining site. Both herbaceous and arborescent plant samples were collected. One-time collection of plants was done in December 2014.

Plant Collection. Each individual plant (either herbaceous or arborescent) species within the sampling area was collected. Two whole plants from each herbaceous species and two branches for each arborescent species were collected, tagged and placed in a Ziploc bag. Plant description for each sample was recorded (Ragragio and Obico, 2011). After collection of herbaceous and arborescent species, these were brought into the field camp for processing before identification and AAS measurements. Standard herbarium preparation was done for unidentified plants.

Processing of Collected Plant Samples. The plant materials were washed with distilled water, blot-dried and then ovendried overnight at $60^{\circ} \mathrm{C}$. The samples were transferred to a pre-weighed crucible for dry ashing in a muffle furnace at $200^{\circ} \mathrm{C}(1 \mathrm{~h})$ then $500^{\circ} \mathrm{C}(4 \mathrm{~h})$. The ash weights were determined after cooling overnight. The plant samples were acid digested by dissolving in $5 \mathrm{~mL} \mathrm{HNO}_{3}$ and heated until the solution volume was reduced to $1 \mathrm{~mL}$. This was repeated twice. After the volume has been reduced to $1 \mathrm{~mL}$, the solution was allowed to cool down to room temperature. Forty $\mathrm{mL}$ of distilled water was then added to each solution and then filtered using Whatman No. 42 filter paper into foilcovered polyethylene bottles. The $\mathrm{pH}$ of each filtrate was adjusted to $\mathrm{pH} 5$ to 7 and the dilution factor was determined and recorded (Baker et al., 2000).

The solutions were then subjected to AAS measurement to determine nickel accumulation at the Chemistry Department of the College of Science at the De La Salle University Manila.

Identification. Plant identification was done at the Philippine National Herbarium. Identification for some plants was also done and verified by Mr. Michael Calaramo, the curator of the Botanical Garden at the Northwestern University in Laoag, llocos Norte.

Data Processing and Interpretation. Nine AAS readings were done for each sample. The readings were then averaged and classified based on the degree of nickel accumulation listed below (Fernando et al., 2013):

Non-nickel accumulator: plants with $<100 \mu \mathrm{g} / \mathrm{g} \mathrm{Ni}$ in dry matter.

Hemiaccumulator: plants with $100-999 \mu \mathrm{g} / \mathrm{g} \mathrm{Ni}$ in dry matter Hyperaccumulator: plants with $>1,000 \mu \mathrm{g} / \mathrm{g} \mathrm{Ni}$ in dry matter Hypernickelophore: plants with $>10,000 \mu \mathrm{g} / \mathrm{g} \mathrm{Ni}$ in dry matter

\section{RESULTS AND DISCUSSION}

A total of 44 species from 30 families were collected from the study site. The plants were classified into non-accumulators, hemiaccumulators, hyperaccumulators and hypernickelophores based on the nickel level ranges determined by AAS and as defined in the work of Fernando et al. (2013). Table 1 lists the plants that are considered non -nickel accumulators.

Table 1 shows that out of 44 species, six were classified as non-nickel accumulators, in which the nickel content was 
Table 1. List of non-nickel accumulator plants $(<100 \mu \mathrm{g} / \mathrm{g} \mathrm{Ni}$ in dry matter)

\begin{tabular}{llll}
\hline Species & Common name & Family & $\begin{array}{l}\text { Nickel content }(\mu \mathrm{g} / \mathrm{g} \mathrm{Ni} \\
\text { in dry matter })\end{array}$ \\
\hline Pterocarpus indicus Willd. & Narra & Fabaceae & 79.56 \\
Melastoma malabathricum L. & Malatungaw & Melastomataceae & 67.63 \\
Rutaceae species & & Rutaceae & 60.05 \\
Mallotus sp. & banato, kamala & Euphorbiaceae & 32.38 \\
Themeda gigantea Hack. & & Poaceae & 31.47 \\
Vaccinium irigaense Merr. & & Ericaceae & 21.36 \\
\hline
\end{tabular}

less than $100 \mathrm{ppm}(1 \mathrm{ppm}=1 \mu \mathrm{g} \mathrm{Ni} / \mathrm{g}$ dry matter). Pterocarpus indicus Willd. belonging to the Fabaceae has the highest mean $\mathrm{Ni}$ level at $79.56 \mathrm{ppm}$ among the non-nickel accumulators, with the lowest value seen in Vaccinium irigaense Merr. at $21.36 \mathrm{ppm}$.

As listed in Table 2, 21 species were classified as hemiaccumulators, having Ni levels ranging from 100 to 999 $\mu \mathrm{g} / \mathrm{g} \mathrm{N}$. Pteridium aquilinum (L.) Kuhn, a fern species belonging to the family Dennstaedtiaceae, is the hemiaccumulator species with the highest mean $\mathrm{Ni}$ content equal to $942.83 \mathrm{ppm}$. The lowest value was found in Sandoricum koetjape (Burm.f.) Merr., the common santo/ fruit tree (107.99 ppm).

As presented in Table 3, there are 11 hyperaccumulators. The highest accumulation of nickel for the hyperaccumulator category was seen in Arundina graminifolia (D. Don) Hochr. of the Orchidaceae family $(8,400 \mu \mathrm{g} / \mathrm{g} \quad \mathrm{N})$. Two other hyperaccumulators belong to the Orchidaceae. The lowest value in this category was detected in Chrysophyllum cainito L. $(1,097.5 \mu \mathrm{g} / \mathrm{g} \mathrm{N})$ of the Sapotaceae.

There are six hypernickelophores as shown in Table 4. The highest nickel content $(22,865 \mu \mathrm{g} / \mathrm{g} \mathrm{N})$ was observed in Lygodium circinnatum (Burm.f.) Swartz, a fern belonging to the family Lygodiaceae. Two other hypernickelophores came from the Asteraceae. Citrus decumana L. or the common pomelo showed the lowest value in this category $(10,631 \mu \mathrm{g} / \mathrm{g}$ N).

Among the ferns, those species from the Blechnaceae, Drynariaceae and Lygodiaceae were noted as hyperaccumulators. One fern, Lygodium circinnatum, was classified as a hypernickelophore, with its $\mathrm{Ni}$ content reaching $22,865.07 \mathrm{ppm}$, which is twice as much as the lower limit of
$10,000 \mathrm{ppm}$ for hypernickelophores. Species from the Dennstaedtiaceae, Gleicheniaceae and Lycopodiaceae were classified as hemiaccumulators, with their Ni levels within the range of $100-999 \mathrm{ppm}$.

The other plant species such as Chromolaena odorata (L.) R.M. King and H. Rob. and Wedelia trilobata (L.) Hitchc. are both invasive alien species. These are prolific and gregarious plants that can colonize and occupy an area within a short period of time. Likewise, these plants can serve as cover crops and can hasten the greening of mining areas. Alstonia macrophylla Wall. ex G. Don and Citrus decumana are both trees and the seeds of these trees may have been brought to the area by birds and bats. Both are native to the area so the reforestation of native species is an important component of restoration and remediation.

This survey identified plants found in the Lagonoy ophiolite complex where nickel mining is currently ongoing. Despite the disturbance, plant growth is lush at some areas which have been mined or along trails used by the miners. The high nickel content of the fern Lygodium circinnatum reflects the ability of this plant to hyperaccumulate heavy metals. The stem of the fern is used as a binding material by local people and can easily grow fast in an open area. Together with other species, Blechnum orientale L. and Drynaria sp., two ferns tested in this study, have the potential to be used in phytoremediation of degraded mining areas in the country. Further collections of plants in the other areas of the Bicol Chromite and Manganese Corporation can be proposed. Other metals can also be determined from the plants growing in the area.

The results of this study affirmed the use of plants with some degree of heavy metal hyperaccumulating properties in phytoremediation efforts. In a developing country affected 
Philippine Journal of Systematic Biology | Bayas, Q.E. et al: Taxonomic Survey of Nickel Hyperaccumulating Plants in Luzon

Table 2. List of nickel hemiaccumulator plants (100-999 $\mu \mathrm{g} / \mathrm{g} \mathrm{Ni}$ in dry matter)

\begin{tabular}{|c|c|c|c|}
\hline Species & Common name & Family & $\begin{array}{l}\text { Nickel content ( } \mu \mathrm{g} / \mathrm{g} \\
\mathrm{Ni} \text { in dry matter) }\end{array}$ \\
\hline Pteridium aquilinum (L.) Kuhn & Bracken fern & Dennstaedtiaceae & 942.83 \\
\hline Syzygium sp. & & Myrtaceae & 864.06 \\
\hline Annona muricata $\mathrm{L}$. & Guyabano & Annonaceae & 848.25 \\
\hline Solanum nigrum $\mathrm{L}$. & Lubi-lubi & Solanaceae & 795.92 \\
\hline Dicranopteris linearis (Burm.) Underw. & Kilob & Gleicheniaceae & 581.67 \\
\hline Odontosoria chinensis (L.) J. Sm. & & Dennstaedtiaceae & 544 \\
\hline Artocarpus heterophyllus Lam. & Langka & Moraceae & 387.22 \\
\hline Nepenthes alata Blanco & Pitcher plant & Nepenthaceae & 361.11 \\
\hline Lycopodiella cernua (L.) Pic. Serm. & staghorn clubmoss & Lycopodiaceae & 324.61 \\
\hline Diospyros blancoi A. DC. & mabolo, kamagong & Ebenaceae & 313 \\
\hline Phragmites sp. & None & Poaceae & 284.79 \\
\hline Albizia procera (Roxb.) Benth. & $\begin{array}{l}\text { Akleng-payang, } \\
\text { payhud }\end{array}$ & Fabaceae-Mimosoideae & 251.67 \\
\hline Colona serratifolia Cav. & None & Malvaceae-Grewioideae & 236.67 \\
\hline Asclepias curassavica L. & $\begin{array}{l}\text { Bulak-damo, } \\
\text { koronitas }\end{array}$ & $\begin{array}{l}\text { Apocynaceae- } \\
\text { Asclepiadoideae }\end{array}$ & 220.43 \\
\hline Syzygium malaccense (L.) Merr. \& L.M. Perry & Makopa & Myrtaceae & 208.42 \\
\hline Casuarina equisetifolia L. & Agoho & Casuarinaceae & 162.43 \\
\hline Tinospora sp. & & Menispermaceae & 159.11 \\
\hline Psidium guajava L. & Bayabas, bayauas & Myrtaceae & 158.72 \\
\hline Dicranopteris linearis (Burm.) Underw. & Kilob & Gleicheniaceae & 156 \\
\hline Passiflora sp. & & Passifloraceae & 133.53 \\
\hline Sandoricum koetjape (Burm.f.) Merr. & Santol & Meliaceae & 107.99 \\
\hline
\end{tabular}


Table 3. List of nickel hyperaccumulator plants (>1000 $\mu \mathrm{g} / \mathrm{g} \mathrm{Ni}$ in dry matter)

\begin{tabular}{llll}
\hline Species & Common name & Family & $\begin{array}{l}\text { Nickel content }(\mu \mathrm{g} / \mathrm{g} \\
\text { Ni in dry matter) }\end{array}$ \\
\hline Arundina graminifolia (D. Don) Hochr. & Bamboo orchid & Orchidaceae & 8400 \\
Blechnum orientale L. & Pakong-alagdan & Blechnaceae & 8187.5 \\
Syzygium curranii (C.B. Robinson) Merr. & Lipote, Baligang & Myrtaceae & 7769.2 \\
Flagellaria sp. & None & Flagellariaceae & 7186.7 \\
Wendlandia glabrata DC. & None & Rubiaceae & 2848.4 \\
Drynaria sp. & None & Drynariaceae & 2202.4 \\
Saccharum spontaneum L. & Talahib & Poaceae & 2023.1 \\
Spathoglottis plicata Blume & Philippine & Orchidaceae- & 1965.4 \\
Ceiba pentandra (L.) Gaertn. & ground orchid & Epidendroideae & \\
Fabaceae species sapling & Kapok & Bombacaceae & 1601.3 \\
Chrysophyllum cainito L. & & Fabaceae & 1524.2 \\
\hline
\end{tabular}

by significant historical and current mining activities like the Philippines where widespread mining activities are conducted with little or no safeguards for environmental well-being resulting to serious soil contamination, the results of this study have serious and important implications. The restoration and rehabilitation of degraded mining sites and their neighboring areas including affected communities represent a major technological and financial challenge. Phytoremediation therefore represents a new and underutilized method in cleaning up contaminated mining sites in the country where expensive technology is largely unavailable and unaffordable. The identification of local plants with hyperaccumulating potentials can contribute to the restoration and conservation of mountain ecosystems like the mining area in Lagonoy, Camarines Sur. Furthermore, the removal of heavy metals from the environment can reduce health risks in mining sites and provide some hope to improve the health status of individuals exposed to high levels of nickel. The identification of these helpful phytoremediation agents and the testing of such in other mining sites should also be pursued.

\section{ACKNOWLEDGEMENTS}

The authors wish to dedicate this paper to the memory of the late Dr. Benito C. Tan, an outstanding botanist who was the foremost expert of Southeast Asian bryology. Dr. Tan had encouraged students to conduct botanical research especially in these times of rapid destruction of the plant resources in the country. The authors would also like to thank the Bicol Chromite and Manganese Corporation for allowing the researchers to collect plants in the mining site, also to the Municipality of Lagonoy for collecting permission. They appreciate the help of the staff of the Philippine National Herbarium and of Mr. Michael Calaramo of the Northwestern University (Laoag City, llocos Norte) for help in identifying the plants. Thanks are extended to the staff of the Chemistry Department of the De La Salle University in Manila for help in AAS measurements.

\section{LITERATURE CITED}

Aloc, J., 2003. Soil characterization and vegetation analysis. Philippine National Agroforestry Committee. Retrieved September 23, 2014 from http://www.pcaarrd.dost.gov.ph/ hom e/momentum/afin/index. ph p ? option $=$ com_content $\&$ view $=$ article $\& i d=514$ : soil characterization-and-vegetation-analysis-at-mount-isarogbuffer-zone\&catid=87\&ltemid=2

Baker, A.J.M., S.P. McGrath, R.D. Reeves, and J.A.C. Smith, 2000. Metal hyperaccumulator plants: A review of the ecology and physiology of a biological resource for phytoremediation of metal-polluted soils, p. 85-107. $\ln \mathrm{N}$. 
Terry and E. Bañuelos (eds.), Phytoremediation of contaminated soil and water. Boca Raton: Lewis Publishers.

Basmayor, M., 2014. LGU Lagonoy wants mining firm in Gimagtocon to stop operation. Bicol Standard. Retrieved September 22, 2014 from http:// www.bicolstandard.com/2014/06/lagonoy-mining-bicolchromite-manganese-corporation.html

Chashschin, V.P, G.P. Artunina, and T. Norseth, 1994. Congenital defects, abortion and other health effects in nickel refinery workers. Science of the Total Environment, 148: 287-291.

Department of Economic Research, 2005. Report on Regional Economic Developments. Retrieved September 23, 2014 from http://www.bsp.gov.ph/publications/ tables/2005_06/news-06022005b1.pdf

Fernando, E.S., M.O. Quimado, L.C. Trinidad and A.I. Doronila, 2013. The potential use of indigenous nickel hyperaccumulators for small-scale mining in the Philippines. Journal of Degraded and Mining Lands Management, 1: 21-26.

Mines and Geosciences Bureau, 2010. Palawan Province. Geology and Mineral Resources. Retrieved from http:// region4b.mgb.gov.ph/?q=palawan-province

Mines and Geosciences Bureau. 2014. The Philippine mineral industry at a glance. Retrieved from http:// w w w . m g b.gov.ph/File s/I t e m Link s / ThePhilippineMineralsIndustryAtAGlance.jpg

Quimado, M.O., E.S. Fernando, L.C. Trinidad and A.I. Doronila, 2015. Nickel-hyperaccumulating species of Phyllanthus (Phyllanthaceae) from the Philippines. Australian Journal of Botany 63(2): 103-110 https:// doi.org/10.1071/BT14284

Ragragio, E. and J. Obico, 2011. Laboratory Manual in Bio 115. UP Manila: Department of Biology.

Wang, L.K., J.-H. Tay, S.T.L. Tay and Y.-T. Hung, eds., 2010. Environmental Bioengineering. Handbook of Environmental Engineering 11. New York, Humana Press. 